\title{
STUDY OF SOLAR DRIVEN ADSORPTION COOLING POTENTIAL IN INDONESIA
}

\author{
Nasruddin Lemington ${ }^{1, *}$, Lemington Lemington ${ }^{1}$, Dylan Budiman ${ }^{1}$, M. Idrus Alhamid ${ }^{1}$, S. Sholahudin ${ }^{1}$ \\ Keywords: Adsorption Chiller; Indonesia Climate; Solar Drive; Pre-heat
}

\begin{abstract}
Indonesia has a big potential in utilizing solar energy. In fact, tropical area like Indonesia has a quite stable solar radiation. This paper presented a study using simulation to investigate the performance of solar driven two bed adsorption chiller based on Indonesia climate. Climatic data of several cities in Indonesia is being used. The chiller is being mathematically modeled and calculated numerically using MATLAB ${ }$. The simulation is run transiently at working hours to achieve temperature in some points in the system. Moreover, additional PCM is also added to the hot water tank in order to achieve a better performance. The results demonstrated the running characteristic of the chiller with the range of COP 0.043-0.342. In general, the chiller performance can reach COP 0.282 with 17 $\mathrm{kW}$ cooling capacity when utilize the solar radiation varies between some cities as input energy. Moreover, Adding PCM in hot water tank also can improve the chiller's performance. Since the amount of heat is essential to the performance of the adsorption chiller, it is better to pre-heat the water before using. By pre-heating and getting the water to a higher temperature, it will generate a higher cooling power needed to meet demand which can be sustained and stable throughout the use of adsorption chiller.
\end{abstract}

\section{INTRODUCTION}

Today, we are experiencing global warming which leads to higher surrounding temperature especially in tropical countries such as Indonesia. Most of electricity generation in Indonesia is still dominated by fossil fuel as main energy source like coal, oil, and gas [1]. It contributes a lot in increasing ambient temperature and concentration of NOx, COx and SOx. In addition, many conventional refrigeration systems used HFC and HCFC refrigerant which has potency on ozone depletion and global warming. The use of natural refrigerant is environmentally friendly [2]; however it is flammable and has low efficiency. Therefore the development of renewable energy for air conditioning can be considered as alternative solution to create clean technology which is safe for environment.

Several researches regarding utilization of solar energy to provide district cooling in the building has been carried out $[3,4]$. Study of biodiesel development is provided in $[5,6]$. In this paper, the study regarding adsorption cooling system will be presented. Unlike conventional air conditioner, adsorption chiller uses heat waste to generate cooling needs without the potential to deplete ozone layers. The low waste heat such as gas burner waste, industrial heat waste, and even heat from the sun can be used by the adsorption chiller to generate cooling. The high level of solar irradiation in Indonesia, can reach 1,000 W/m2 on average at the ground surface during mid-day [7], which is more than enough to be used for adsorption chiller. An adsorption system has several advantages, including simple control mechanism, low operating costs and lower vibration levels [8] even though the COP is generally low at range 0.043-0.342.

Silica-gel has been widely used as an adsorbent in adsorption cooling but in this simulation, we use zeolite as the adsorbent. Zeolite is a more abundance and cheaper alternative to silica-gel which means it is easier to get than silica-gel. When using zeolite as an adsorbent, the heat input is usually need to be higher than that of silicagel for the system to run. In general, the chiller performance can reach COP 0.282 with $17 \mathrm{~kW}$ cooling capacity when utilize the solar radiation varies between some cities as input energy. However, in this simulation we want to know the effect of initial hot water temperature to the performance of the adsorption chiller by analyzing the outlet temperature of chilled water and the cooling capacity.

\section{SYSTEM DESCRIPTION}

The adsorption chiller is based on the model developed by Shanghai Jiao Tong University by Pan et al [8]. The schematic of an adsorption chiller on figure 1 shows the schematic of the model chiller. The chiller contains 2 adsorbers, 2 condensers, and 2 evaporators.

This paper was recommended for publication in revised form by Regional Editor Omid Mahian ${ }^{1}$ Mechanical Engineering Department, Universitas Indonesia, Depok, Indonesia

*E-mail address: p.heidarnejad@ut.ac.ir 


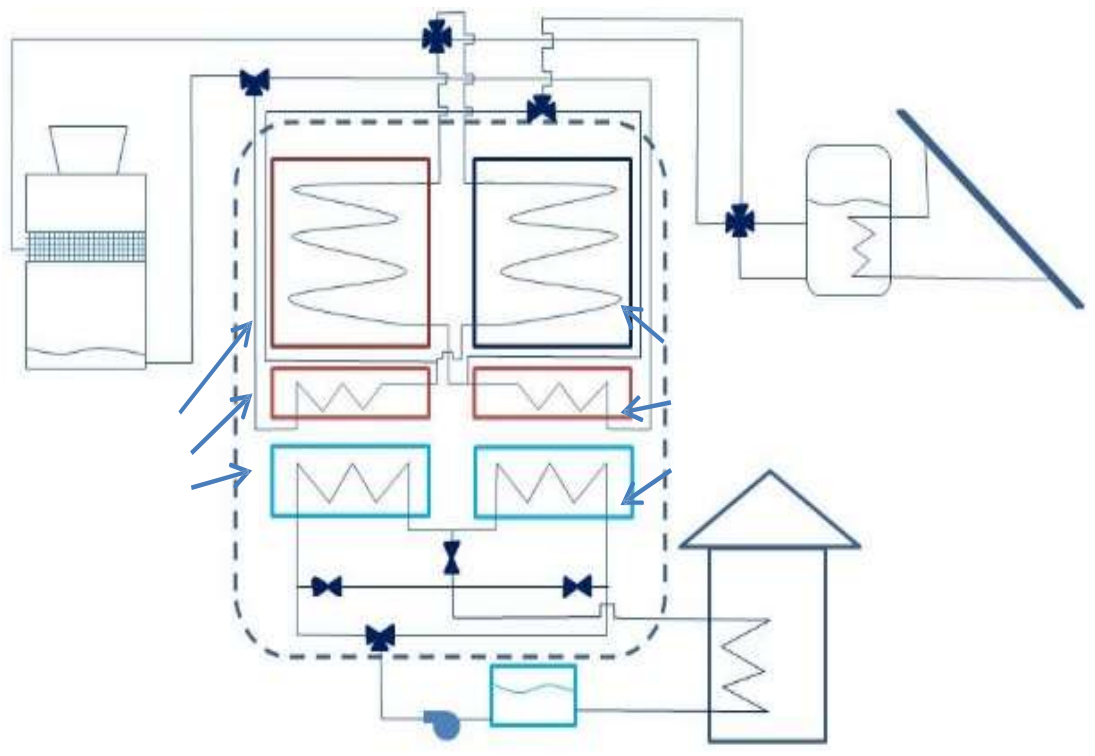

Figure 1. Schematic of Adsorption Chiller [9]

The adsorption chiller uses two bed so that the adsorption-desorption process can be done simultaneously and the chilled water can be produce continuously. The hot water is supplied to and from the solar hot water collector, cool water is supplied to and from cooling tower, and chilled water is supplied to the load that needs cooling.

\section{MATHEMATICAL MODELLING}

The mathematical modeling is based on heat transfer principles inside the system for the water inlet and outlet of the system. The simulation properties and constants are shown in Table 1.

\section{Adsorption Isotherms} by

The non-equilibrium equation of adsorption isotherms of zeolite-water adsorption kinetics is expressed

$\frac{d x}{d t}=15 D_{s o} \exp \left(-\frac{E a}{R} \cdot T b\right) \frac{\left(X^{*}-X\right)}{\left(R_{p}^{2}\right)}$

Where $\mathrm{X}^{*}$ is the equilibrium capacity in the adsorber and can be calculated with Dubinin-Radushkevich model [10]

$X^{*}=X_{o} \exp \left[-k\left(\frac{T b}{T_{s a t}}-1\right)^{n}\right]$

Where $\mathrm{X}_{\mathrm{o}}$ is the maximum water uptake value of zeolite-water, $\mathrm{k}$ and $\mathrm{n}$ are dimensionless constants. The value is given in table 2 .

\section{Adsorption and Desorption Process}

The adsorption chiller uses solar energy as a heat input. The solar energy equation is expressed as [9]

$q=\eta A_{\text {solar panel }} J$ as shown in

The heat from the solar panel is transferred to the hot water held in a tank. The energy balance is calculated

$$
C_{p, w} M_{h w t, w} \frac{d T_{h, i n}}{d t}=q+\dot{m}_{h w} C_{p, w}\left(T_{h, \text { in }}-T_{h, o u t}\right)
$$


Table 1. Parameter of simulation [9]

\begin{tabular}{|l|l|l|}
\hline Parameters & Value & Unit \\
\hline Ac & 400 & $\mathrm{~m}^{2}$ \\
\hline $\mathrm{H}$ & 0.35 & $\%$ \\
\hline Ca & 836 & $\mathrm{~J} / \mathrm{kg} /{ }^{\circ} \mathrm{C}$ \\
\hline Cal & 905 & $\mathrm{~J} / \mathrm{kg} /{ }^{\circ} \mathrm{C}$ \\
\hline Ccu & 386 & $\mathrm{~J} / \mathrm{kg} /{ }^{\circ} \mathrm{C}$ \\
\hline $\mathrm{Cp}, \mathrm{w}$ & 4180 & $\mathrm{~J} / \mathrm{kg} /{ }^{\circ} \mathrm{C}$ \\
\hline Cw,v & 1850 & $\mathrm{~J} / \mathrm{kg} /{ }^{\circ} \mathrm{C}$ \\
\hline Dso & $3.92 \mathrm{E}-06$ & $\mathrm{~m}{ }^{2} / \mathrm{s}$ \\
\hline Ea & $2.80 \mathrm{E}+04$ & $\mathrm{~J} / \mathrm{mol}$ \\
\hline$\Delta \mathrm{H}$ & $3.40 \mathrm{E}+06$ & $\mathrm{~J} / \mathrm{kg}$ \\
\hline UAad & 51315 & $\mathrm{~W} /{ }^{\circ} \mathrm{C}$ \\
\hline UAc & 79326.5 & $\mathrm{~W} /{ }^{\circ} \mathrm{C}$ \\
\hline UAe & 35352.6 & $\mathrm{~W} /{ }^{\circ} \mathrm{C}$ \\
\hline $\mathrm{L}$ & $2.50 \mathrm{E}+06$ & $\mathrm{~J} / \mathrm{kg}$ \\
\hline Ma & 200 & $\mathrm{~kg}$ \\
\hline Mtube & 94.85 & $\mathrm{~kg}$ \\
\hline Mfin & 48.8 & $\mathrm{~kg}$ \\
\hline Mc & 172.62 & $\mathrm{~kg}$ \\
\hline Me & 471.68 & $\mathrm{~kg}$ \\
\hline R & 8.314 & $\mathrm{~J} / \mathrm{mol} /{ }^{\circ} \mathrm{C}$ \\
\hline$m_{\text {hw }}$ & 6.8055 & $\mathrm{~kg} / \mathrm{s}$ \\
\hline$m_{\text {chill }}$ & 2.63888 & $\mathrm{~kg} / \mathrm{s}$ \\
\hline$m_{\text {co ol }}$ & 9.583 & $\mathrm{~kg} / \mathrm{s}$ \\
\hline Mhwt,w & 2180 & $\mathrm{~kg}$ \\
\hline Rp & 0.0005 & $\mathrm{~m}$ \\
\hline
\end{tabular}

Table 2. Constants for adsorption isotherm

\begin{tabular}{|l|c|c|c|}
\hline Parameter & $\mathrm{X}_{\mathrm{o}}(\mathrm{kgw} / \mathrm{kgad})$ & $\mathrm{k}$ & $\mathrm{n}$ \\
\hline Adsorption & 0.1219 & 5.052 & 1.4 \\
\hline Desorption & 0.1249 & 3.62 & 1.2 \\
\hline
\end{tabular}

The energy balance of the bed is expressed as

$$
\begin{aligned}
& \frac{d T_{b}}{d t}\left[M_{a d}\left(C_{a d}+C_{p, w} X\right)+C_{c u} M_{t u b e, a d}+C_{a l} M_{f i n, a d}\right]=M_{a d} \Delta H \frac{d x}{d t}+\dot{m}_{h w} C_{p, w}\left(T_{a d, i n}-T_{a d, o u t}\right)- \\
& \quad \delta M_{a} C_{w, v}\left(T_{b}-T_{e}\right) \frac{d x}{d t}
\end{aligned}
$$

With $\delta$ acts as a logic value where:

$\delta=1$ is for an adsorption process, and $\delta=0$ is for a desorption process.

The temperature difference is expressed as

$\frac{\left(T_{a d, o u t}-T_{b}\right)}{\left(T_{a d, i n}-T_{b}\right)}=\exp \left[\frac{-U A_{a d}}{\dot{m}_{h w} C_{p, w}}\right]$

For the energy equilibrium, the condenser energy balance is given by

$$
M_{c} C_{c u} \frac{d T_{c}}{d t}=(1-\delta)\left[-L M_{a} \frac{d x}{d t}\left(T_{c}-T_{b}\right)\right]+\dot{m}_{c o o l} C_{p, w}\left(T_{c o o l, i n}-T_{c o o l, o u t}\right)
$$

With the temperature difference is expressed as

$$
\frac{\left(T_{\text {cool }, \text { out }}-T_{C}\right)}{\left(T_{\text {cool }, \text { in }}-T_{C}\right)}=\exp \left[\frac{-U A_{C}}{\dot{m}_{\text {cool }} C_{p, w}}\right]
$$


The evaporator energy balance is therefore given by

$$
\begin{aligned}
& \frac{d T_{e}}{d t}\left[M_{e, w} C_{p, w}+C_{c u} M_{e}\right]=\delta\left[-L M_{a} \frac{d x}{d t}+\dot{m}_{c h i l l} C_{p, w}\left(T_{c h i l, \text { in }}-T_{c h i l, \text { out }}\right)\right]+(1-\delta)\left[\theta C_{p, w}\left(T_{e}-T_{c}\right) M_{a} \frac{d x}{d t}-\right. \\
& \left.(1-\theta) L M_{a} \frac{d x}{d t}\right]
\end{aligned}
$$

Where $\Theta$ is a flag equation, which has a value of:

$$
\theta=1 \text { if } T_{c} \leq T_{e} \text {, while } \theta=0 \text { if } T_{c}>T_{e}
$$

The temperature difference is expressed as

$\frac{\left(T_{\text {chill }, \text { out }}-T_{e}\right)}{\left(T_{\text {chill }, \text { in }}-T_{e}\right)}=\exp \left[\frac{-U A_{e}}{\dot{m}_{\text {chill }} C_{p, w}}\right]$

\section{Mass and Heat Recovery Equations}

Mass and heat recovery are critical to the adsorption and desorption process as it will increase overall efficiency. The energy balance for mass recovery used is expressed as

$$
\begin{aligned}
& \frac{d T_{e}}{d t}\left[M_{e, w} C_{p, w}+C_{c u} M_{e}\right]=\delta\left[-L M_{a} \frac{d x}{d t}+\dot{m}_{\text {chill }} C_{p, w}\left(T_{\text {chill,in }}-T_{\text {chill,out }}\right)\right]+(1-\delta)\left[\theta C_{p, w}\left(T_{e}-T_{c}\right) M_{a} \frac{d x}{d t}-\right. \\
& \left.(1-\theta) L M_{a} \frac{d x}{d t}\right]-(1-\zeta)\left[C_{p, w}\left(T_{\text {chill,in }}-T_{\text {chill,out }}\right)\right]
\end{aligned}
$$

Where $T_{\text {chill,in' }}$ is the chilled water outlet temperature after the chilled water flows through the inactive evaporator and $\zeta$ represents the flag values of 1 and 0 , when the evaporator is active and inactive, respectively.

There is no change in the energy balance of heat recovery, however there are substitute variables as shown

$T_{a d, o u t, a d s}=T_{a d, i n, d e s}$

$T_{\text {cool,out }}=T_{\text {ad,out,des }}$

\section{Cooling Capacity and COP}

The performance is judged using the most common parameter which is COP. The COP is calculated using a basic formula that is the ratio between the cooling capacity $(\mathrm{Qr})$ and heating power $(\mathrm{Qh})$ as shown

$$
\begin{aligned}
& Q_{r}=\int_{0}^{t_{c y c l e}} C_{p, w} \dot{m}_{c h i l l}\left(T_{\text {chill,in }}-T_{\text {chill }, \text { out }}\right) \frac{d t}{t_{\text {cycle }}} \\
& Q_{h}=\int_{0}^{t_{c y c l e}} C_{p, w} \dot{m}_{h w}\left(T_{h, \text { in }}-T_{h, \text { out }}\right) \frac{d t}{t_{\text {cycle }}} \\
& \text { COP }={ }^{Q_{r}} / Q_{h}
\end{aligned}
$$

\section{RESULTS AND DISCUSSION}

The simulation of adsorption chiller uses MATLAB ${ }^{\circ}$ as simulator software using Euler numerical method as computation. We are testing for two heat input which is $60^{\circ} \mathrm{C}$ and $80^{\circ} \mathrm{C}$ to see if it has an effect on the chiller performance. The half-cycle time is $864 \mathrm{~s}, 800$ s cooling time, $40 \mathrm{~s}$ mass recovery, $24 \mathrm{~s}$ heat recovery running for 10 cycles.

The solar heat input is based on the average daily value of solar intensity in Depok, Jawa Barat which can be seen on Figure 2. In this simulation, it is assumed that the start of the simulation is at 8 A.M. 


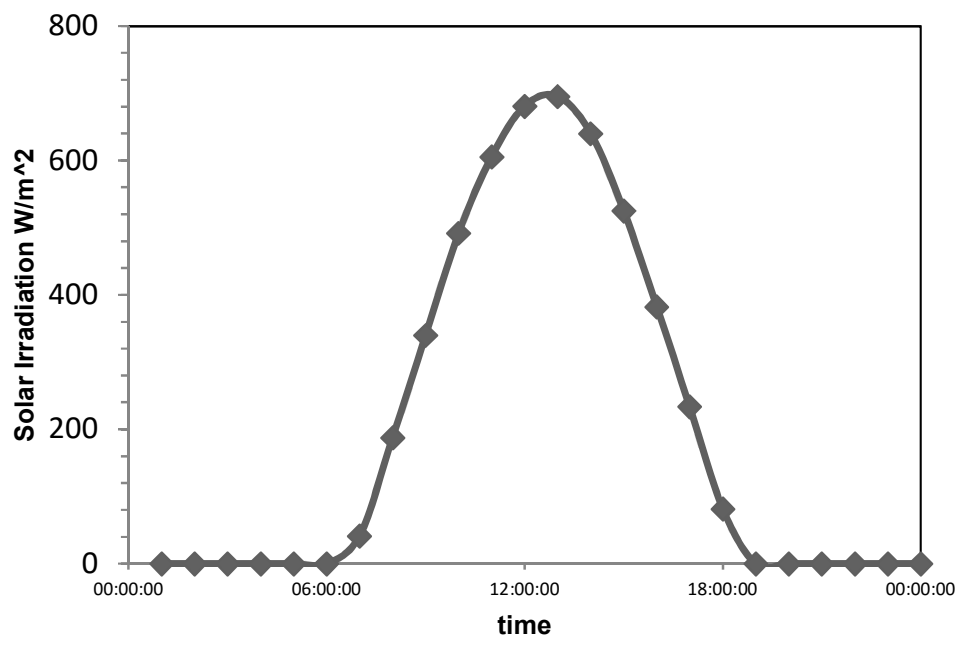

Figure 2. Daily solar irradiation, Depok, Indonesia

The results of the simulation are given in Figure 3 and Figure 4.

\section{Chilled Water Outlet Temperature}

As we can see at figure 3, the chilled water outlet temperature is cooler at high hot water inlet. In this case, the chilled water outlet can get as low as $10^{\circ} \mathrm{C}$ with $80^{\circ} \mathrm{C}$ initial hot water inlet compared to $11.5^{\circ} \mathrm{C}$ with $60^{\circ}$ $\mathrm{C}$ initial hot water inlet. With more heat at the inlet means that the desorption capabilities will be better so the zeolite will have less water content to then be able to adsorb more during the adsorption process, thus creating less pressure on bed and generate more cooling.

During this 10 cycle, we can see the trend of the hot water inlet with the use of solar collector. We can see that in figure $3 \mathrm{a}$ that the hot water inlet increase over time and reached $70^{\circ} \mathrm{C}$ in 2.4 hours while in figure $3 \mathrm{~b}$, the hot water inlet slightly decrease but in the end still maintain $80^{\circ} \mathrm{C}$ water inlet at the end of 2.4 hours. While the increasing temperature in figure $3 \mathrm{a}$ is attributed to increasing solar intensity during the process, it is the slight decrease in figure $3 \mathrm{~b}$ that captures our attention. The slight decrease is due to the fact that during the desorption process, more heat is then release to desorb the water which then lower the outlet temperature to the solar collector. With the solar collector still at low input irradiation, the inlet temperature will then be lower than the previous until the solar irradiation picks up.

\section{Cooling Capacity}

Looking at the cooling capacity of the simulated system, we can see that the cooling capacity is generally higher and more constant at higher inlet temperature compared to the lower one. This is due to the colder generation of the chilled water at higher initial temperature which means that the ability to cool is significantly higher than those with lower initial temperature. The striking part is that the cooling capacity in figure $4 \mathrm{~b}$ is very stable compared to figure $4 \mathrm{a}$ which shows increasing cooling power overtime. This becomes a major talking point because in order to get the cooling power required to cool the room, the one with a lower starting temperature will need more time to reach it while the one that is "pre-heated" or have a higher starting temperature will generate a stable and higher cooling power from the start. 
Journal of Thermal Engineering, Technical Note, Vol. 3, No. 1, pp. 1044-1051, January, 2017

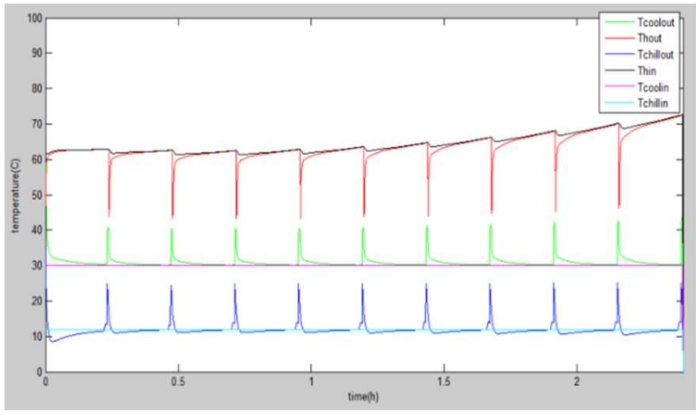

(a)

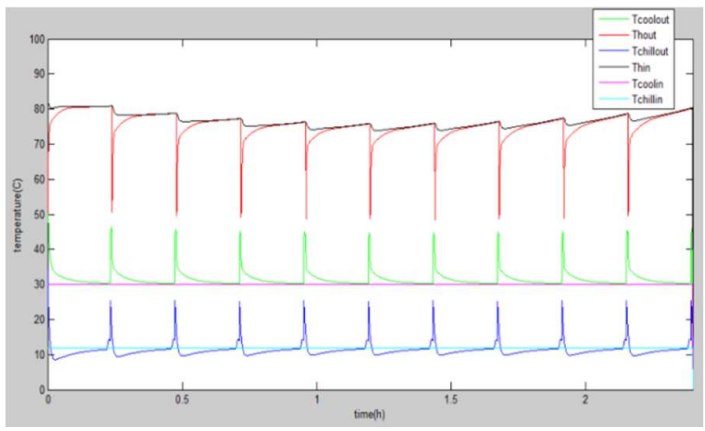

(b)

Figure 3. Water Outlet Temperature (a) $60^{\circ}$ input heat (b) $80^{\circ}$ input heat

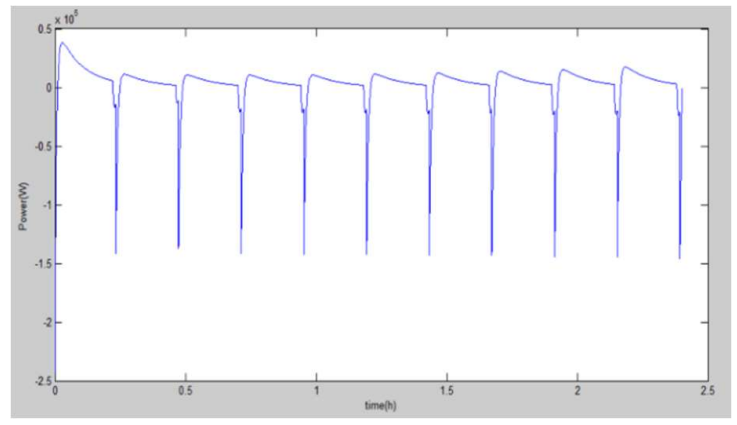

(a)

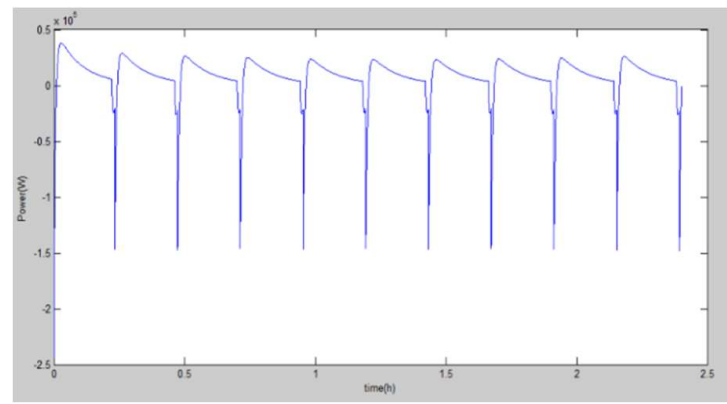

(b)

Figure 4. Cooling Capacity (a) 60o input heat (b) 80o input heat 


\section{CONCLUSION}

The simulation of zeolite-water adsorption chiller is being developed and investigated in this research. The aim is to make adsorption chiller well known and efficient enough to be used commercially and to replace conventional air conditioners. Waste heat can be used in adsorption chiller with varying degree of performance. In a zeolite-water adsorption chiller, higher starting temperature means:

- Colder chilled water outlet

- Higher cooling power generated

- More stable cooling power generated

This simulation shows that when using a solar driven adsorption chiller for cooling purposes, one must "pre-heat" the hot water first before using it. Doing this will give a higher cooling power to meet demands from the start while maintaining its stability throughout the day.

\section{ACKNOWLEDGMENTS}

This work is supported by Hibah Riset Kolaborasi Internasional Tahun Anggaran 2015 No. 1785/UN2.R12/HKP.05.00/2015 and Hibah Penelitian Unggulan Perguruan Tinggi Tahun Anggaran 2016 No. 1169/UN2.R12/HKP.05.00/2016

\section{NOMENCLATURE}

$\begin{array}{ll}\Delta \text { Hads } & \text { Isosteric heat of adsorption, } \mathrm{J} / \mathrm{kg} \\ \mathrm{Ac} & \text { Area of the solar collector, } \mathrm{m}^{2} \\ \mathrm{~A} & \text { Area, } \mathrm{m}^{2} \\ \mathrm{COP} & \text { Coefficient of performance } \\ \mathrm{Cp} & \text { Specific heat, } \mathrm{kJ} /(\mathrm{kg} \mathrm{K}) \\ \mathrm{d} / \mathrm{dt} & \text { Change rate, } 1 / \mathrm{s} \\ \mathrm{Dso} & \text { Pre-exponential constant, } \mathrm{m}^{2} / \mathrm{s} \\ \mathrm{dT} / \mathrm{dx} & \text { Average temperature gradient, } \mathrm{K} / \mathrm{m} \\ \mathrm{Ea} & \text { Activation energy, } \mathrm{J} / \mathrm{mol} \\ \mathrm{g} & \text { Gravitational acceleration, } \mathrm{m} / \mathrm{s}^{2} \\ \mathrm{~L} & \text { Latent heat of vaporization, } \mathrm{J} / \mathrm{kg} \\ \mathrm{J} & \text { Solar irradiation, } \mathrm{J} / \mathrm{m}^{2} \\ \mathrm{M} & \text { Mass, } \mathrm{kg} \\ \mathrm{m} & \text { Mass flow rate, } \mathrm{kg} / \mathrm{s} \\ \mathrm{P} & \text { Pressure, } \mathrm{kPa} \\ \mathrm{q} & \text { solar heating power, } \mathrm{kW} \\ \mathrm{Q} & \text { Heat, } \mathrm{kW} \\ \mathrm{R} & \text { Universal gas constant, } \mathrm{J} /(\mathrm{mol} \mathrm{K}) \\ \mathrm{Rp} & \text { Particle radius, } \mathrm{m} \\ \mathrm{T} & \text { Temperature, } \mathrm{K} \\ \mathrm{t} & \text { Time, } \mathrm{s} \\ \mathrm{U} & \text { Overall conductance, } \mathrm{kW} / \mathrm{K} \\ \mathrm{X} & \text { Uptake value, } \mathrm{kgw} / \mathrm{kgZeolite} \\ \mathrm{X} * & \text { Equilibrium uptake, } \mathrm{kgw} / \mathrm{kgZeolite} \\ \eta & \text { efficiency of solar collector } \\ & \end{array}$

$\begin{array}{ll}\text { Greek symbols } & \\ \Delta & \text { Difference } \\ \Sigma & \text { Summation } \\ \Theta & \text { Flag } \\ \delta & \text { Logic value } \\ \xi & \text { Flag }\end{array}$




\begin{tabular}{ll} 
Subscripts & \\
ad & Adsorbent \\
al & aluminium \\
b & Bed \\
chill & Chilled water \\
c & Condenser \\
cool & Cooling water \\
eff & Effective \\
e & Evaporator \\
h & Hot water \\
ht & Hot water tank \\
in & Inlet \\
out & Outlet \\
sat & Saturation \\
w & water \\
v & Water vapor \\
Superscript & \\
$\cdot$ & Rate \\
- & Average \\
REFERENCES & \\
\hline &
\end{tabular}

[1] Nasruddin, Alhamid, M.I., Daud, Y., Surachman, A., Sugiyono, A., Aditya, H.B., Mahlia, T.M.I., 2016, Potential of geothermal energy for electricity generation in Indonesia: A review, Renewable and Sustainable Energy Reviews 53:733-740

[2] Kutlu, C., Ünal, S., Erdinç, M.T., 2016, Thermodynamic Analysis of Bi-Evaporator Ejector Refrigeration Cycle Using R744 as Natural Refrigerant, Journal of Thermal Engineering 2:735-740

[3] Arora, A., Dixit, M., Kaushik, S.C., 2016, Energy and Exergy Analysis of A Double Effect Parallel Flow $\mathrm{LiBr} / \mathrm{H}_{2} \mathrm{OAbsorption}$ Refrigeration System, Journal of Thermal Engineering 2:541-549

[4] Arora, A., Dixit, M., Kaushik, S.C., 2016, Computation of Optimum Parameters of A Half Effect WaterLithium Bromide Vapour Absorption Refrigeration System, Journal of Thermal Engineering 2:683-692

[5] Silitonga, A.S., Masjuki, H.H. Mahlia, T.M.I., Ong, H.C., Kusumo, F., Aditiya, H.B., Ghazali, N.N.N., 2015, Schleichera oleosa L oil as feedstock for biodiesel production, Fuel 156: 63-70

[6] Dharma, S., Masjuki, H.H., Ong, H.C., Sebayang, A.H., Silitonga, A.S., Kusumo, F., Mahlia, T.M.I., 2016, Optimization of biodiesel production process for mixed Jatropha curcas-Ceiba pentandra biodiesel using response surface methodology, Energy Conversion and Management 115: 178-190

[7] Gerrit Jacobs, (2010), Training Course on Renewable Energy Part II, MEMR-CASINDO, Jakarta 14-18 June 2010

[8] Pan, Q.W., Wang, R.Z., Wang, L.W., Liu, D., 2014. Design and Experimental Study of Adsorption Chiller with Module Type Adsorber. In: Proceedings of the International Conference of Solar Heating and Cooling for Building and Industry, SHC 2014, Beijing, 13-15 October 2014

[9] Nasruddin, Lemington, Alhamid, M.I., 2015, Numerical Simulation of a Two-Bed Solar-Driven Adsorption Chiller in a Tropical Climate, IJTech 4: 594-603

[10] Ismail Solmus, Yamal Cemil, Kaftanog $`$ lu Bilgin, Baker Derek, Cag $`$ lar Ahmet, 2010, Adsorption properties of a natural zeolite-water pair for use in adsorption cooling cycles, Applied Energy 87: 2062-2067 